Available online at

http://ojs.unik-kediri.ac.id/index.php/ukarst/index

U KaRsT

doithttp://dx.doi.org/10.30737/ukarst.v5i2

\title{
Reduce Flood Losses Of Kali Tanggul Using Spatial Based Technical
}

\section{Approaches}

\author{
P. Prabowo ${ }^{1}$, G. Halik ${ }^{2 *}$, E. Hidayah ${ }^{3}$, T. Haq ${ }^{4}$ \\ 1,2,3,4 Civil Engineering Department, Jember University. \\ Email:2* gusfan.teknik@unej.ac.id
}

\begin{tabular}{ll}
\hline A R T I C L E I N F O \\
\hline Article History : \\
Article entry $: 04-05-2021$ \\
Article revised $: 22-05-2021$ \\
Article received $: 16-07-2021$ \\
\hline
\end{tabular}

Keywords :

Flood Inundation Model, GIS, HEC-RAS, Tanggul Watershed, Shortcut.

IEEE Style in citing this article : [1] A. D. Wicaksono, E. Hidayah, and R. U. A. Wicaksono, "Flood Vulnerability Assessment of Kali Welang Floodplain by Using Analytic Hierarchy Process Based Methods," Ukarst, vol. 5, no. 1, pp. 95-109, 2021, doi: 10.1016/j.gloenvcha.2006.03.008

\section{A B S T R A C T}

Flood disasters frequently occurred in Jember Regency, East Java. It is usually caused by the overflow of the Tanggul River in the rainy season, especially in the downstream area. Flood control could be done by building dams, embankments, shortcuts, and other technical flood protections. Meanwhile, mitigation efforts such as developing thematic maps of flood inundation need to be done to minimize losses caused by the flood. This study aims to design a flood mitigation strategy technically. The flood control structure was proposed by designing a shortcut in Kali Tanggul. Its performance was analyzed to reduce flood inundation in the Tanggul watershed. The flood inundation modeling was carried out using spatial analysis using ArcGIS 10.1 and hydraulic analysis using HECRAS 5.0.3. Flood inundation results were compared with the Tanggul watershed flood map developed by UPT PUSDA Lumajang. Based on modeling results, flood control using shortcuts is considered an effective strategy for flood mitigation. It was indicated by the reduction of flood inundation distributions, flood inundation height, and flood-affected areas. The results show that the flood height decrease 0.47 up to 0.56 $\mathrm{m}$

\section{Introduction}

Some parameters affect the flood vulnerability index. They consist of six parameters for exposure (rainfall intensity, topographic, closeness to the river, primary construction material for roof, walls, and floor, position of buildings to the street level, and building density), nine parameters for susceptibility (land use, type of soil, tidal range, age, gender, level of education, traffic density, income, dan livelihood), and three parameters for resilience (experience with flood, knowledge about flood hazard, and knowledge about private protection measures) [1][2]. In general, efforts to minimize the threat of flooding done by building dams 
[3],embankments [4], [5], shortcuts, or other flood control buildings. Mitigation efforts, such as making maps of flood inundation distribution, has needed to minimize damage [6][1].

The Tanggul watershed, which located in Tanggul, Jember, is often hit by floods. Based on the observations of UPTD Kencong and Sumber Baru, Tanggul watershed in the last ten years, data shows that flooding in this location has almost occurred every year. The condition of the embankment river, which tends to be narrow, winding, and has many complex plants at riverbeds such as bananas, can obstruct the flow, especially when the river discharge increases due to rain.

There have been 27 floods in the Tanggul watershed in the last 25 years, nine times break the river embankment. The most recent incident occurred on December 22nd, 2018, which broke down along $60 \mathrm{~m}$ with a height of $7.2 \mathrm{~m}$ which caused the river flow to turn rapidly into rice fields and residential areas. recorded that the water level reached $3.5 \mathrm{~m}$ with a discharge of 749,153 m3. There are 595 houses in three villages, namely Kecong, Kraton, and Paseban Villages, and 345 rice fields flooded. This condition makes the Tanggul watershed an area that has a high risk of flood. The facts above show that the impact of flood discharge in the Tanggul River still occurs every year.

Some efficient technologies used to evaluate flood hazards on a much-developed regional scale. Various models integrated with Geographical Information Systems (GIS) have developed a lot, one of which is the integration of ArcGIS and HEC-RAS [7], [8]. GIS is a system or program for storing data related to various events on earth [9]. Based on previous research [7], [8], [10]-[12]. GIS has been used successfully in displaying and analyzing regions, visual inundation to produce a risk map of flood distribution. The flow profile determination is the basis of flood tracking analysis and research on applying the Hydrologic Engineering Center - River Analysis System (HEC-RAS) model to simulate water levels that has been widely used, both at home and abroad[13][14]. Several components or features of the ease of HEC-RAS include analysis of steady and unsteady flow water profiles [15], sediment transport analysis [16], [17], and water quality analysis.[18]. These components consist of geometry data, flow hydraulic formulations, and other hydraulic design features that can be accessed if the flow computation process is successfully executed [19][20].

This study aimed to determine the effectiveness of the shortcut as a flood control strategy to design mitigation efforts or reduce the risk of flood inundation in the Tanggul watershed. The effectiveness of the shear in terms of spatial inundation at various times of return: 25, 50, 100, 200, 500, and 1000 years Thus, it will obtain a description and information 
of flood inundation hazard areas. A combination of technical structures with a flood inundation distribution map can made by modeling and simulating flood inundation at the Tanggul River's downstream using the ArcGIS 10.1 and HEC-RAS 5.0.3 programs

\section{Research Method}

The Tanggul watershed divided into two sub-watersheds: the Tanggul's upstream subwatershed and the Watu Urip sub-watershed. The research location is downstream of the Tanggul watershed, with an area of $258,122 \mathrm{~km} 2$. Flood inundation analysis done along 23.5 $\mathrm{km}$ of the Tanggul River. Meanwhile, the shortcut plan is made at the Kali Tanggul bend around $11.7 \mathrm{~km}$ from the downstream, as shown in Figure 1.

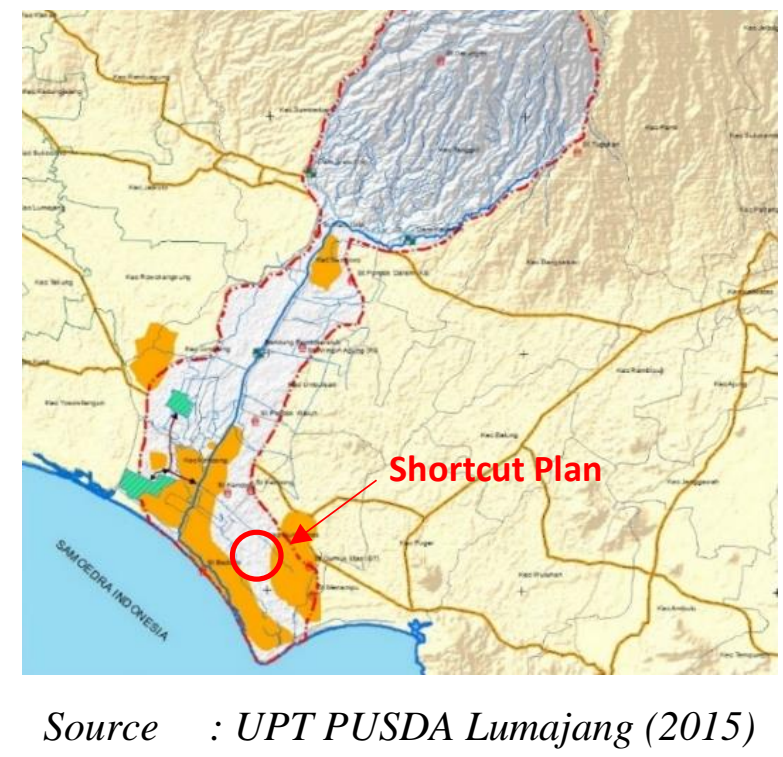

Figure 1. Research Location

The research stages are stated in the research flow diagram, as shown in Figure 2. Data collection includes the Tanggul river geometry data from the Embankment bridge to the estuary or downstream, rainfall data, and administrative maps of the Tanggul watershed, sourced from the UPTD PUSDA Lumajang. Topographic data is in the form of a The type of data used for running ArcGIS is Digital Elevation Model (DEM) with a resolution of $25 \mathrm{~m}$ obtained from SRTM satellite imagery and the Geospatial Information Agency (BIG). Using DEM is costeffective for obtaining fit-for-purpose flood maps cause it improves flood modeling without surveying the entire model extent when financial and practical limitations [21][22].

Flood inundation modeling in the Tanggul watershed includes several input components. These components include Digital Elevation Model (DEM), river geometry, and input discharge data at various return times. The river geometry is obtained from the curved 
measurements by the UPTD PUSDA Lumajang. The measurement of river geometry, both longitudinal and transverse, is carried out along $\pm 20 \mathrm{~km}$. The DEM used is DEM ASTER with A resolution of $25 \times 25 \mathrm{~m}$ from the USGS. This DEM data has low accuracy so that a new DEM is compiled in the TIN format, which is built from a combination of vectors and raster [23].

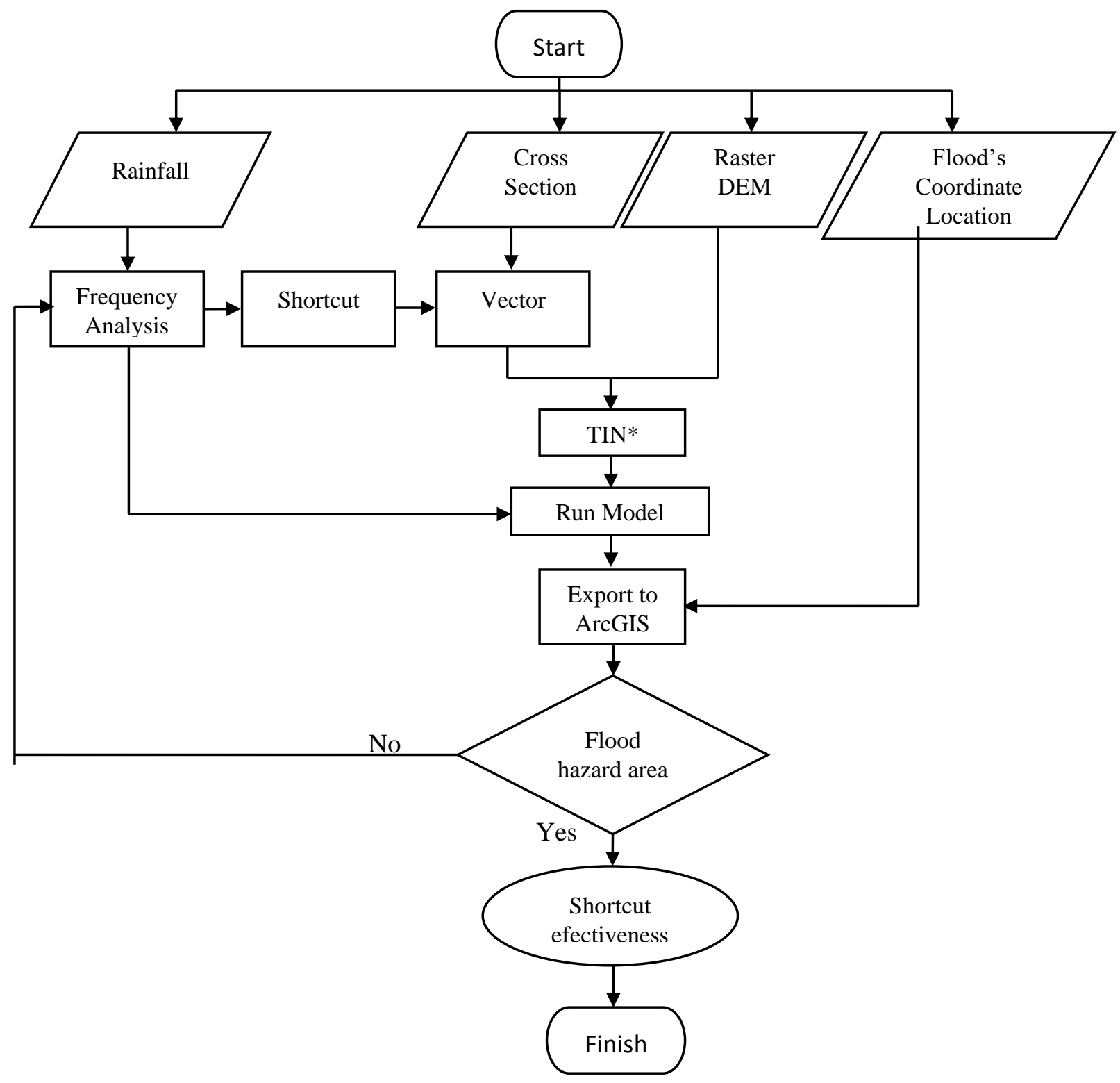

$*$ TIN $=$ Triangular Irregular Networks

\section{Source : Research document (2021)}

Figure 2. Research Flowchart

The next stage is modeling the shortcut at Kali Tanggul. Planning and calculation of the shortcut are carried out based on the design flood at various times. Hydraulic analysis was carried out to study the flood characteristics before and after the construction of the shortcut. Meanwhile, a flood inundation map was created using a hydraulic approach combined with a 
raster (GIS) to limit the flood-affected areas [24]. Making a flood distribution map is done by performing a 2-dimensional flood simulation with the help of the HEC-RAS version 5.03 program by utilizing the RAS Mapper feature[25].

Whether there is no wave or after a wave, the prediction of flood inundation is analyzed on various flood discharges, such as floods during the 25, 50, 100, 200, 500, and 1000 years return period. The return flood discharge was analyzed based on rainfall for 15 years (20042018) with distribution frequency (Log Pearson III) from the distribution suitability test with the Chi-Square and Smirnov-Kolmogorov tests to find out the truth of the frequency hypothesis [26]. Furthermore, the design discharge obtained by transforming the rain stream using the Nakayasu Synthetic Unit Hydrograph concept approach.

\section{Results and Discussions}

\subsection{Flood Discharge}

River geometry data and flood discharge data for various times were included as conditions for the upstream boundary. Flood discharge data at different return periods are shown in Table 1, while the flood hydrograph at various return periods is shown in Figure 3. The downstream boundary conditions are in the form of tidal data.

Table 1. Flood Discharge on Various Return Period

\begin{tabular}{c|c}
\hline Return Period & Discharge $\left(\mathrm{m}^{3} / \mathrm{dt}\right)$ \\
\hline 20 & 407.204 \\
25 & 468.488 \\
50 & 541.632 \\
100 & 622.732 \\
200 & 702.732 \\
1000 & 934.098 \\
\hline
\end{tabular}

Source : Research document (2021)

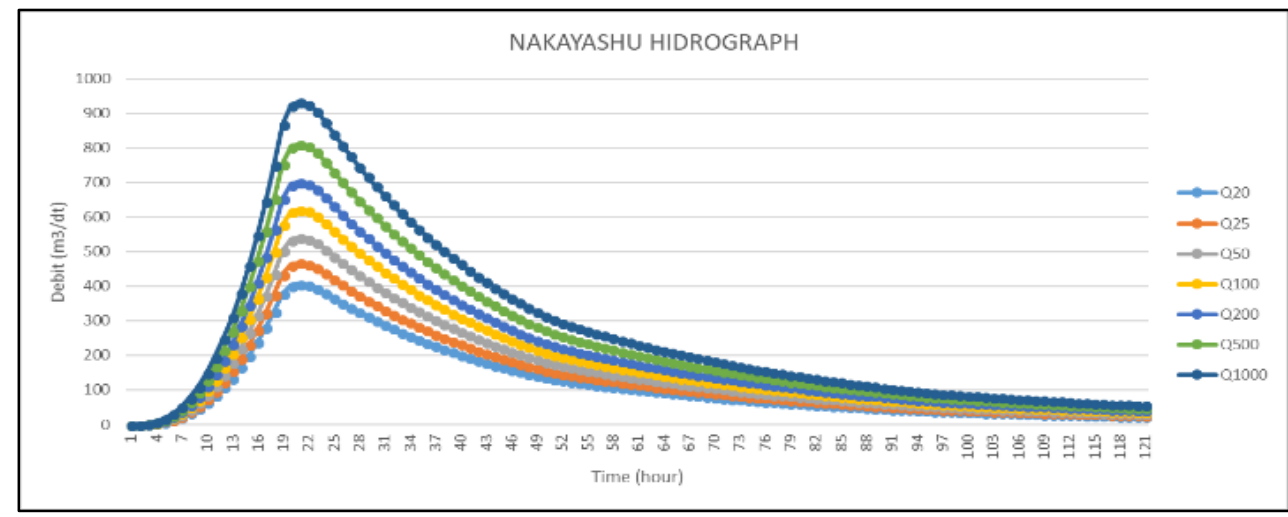

Source : Research document (2021)

Figure 3. Nakayasu Synthetic Hydrograph 


\subsection{Shortcut Design}

The shortcut planning is analyzed at the highest return period flood discharge (934.098 $\mathrm{m}^{3} / \mathrm{s}$ ) so that the shortcut design results can drain the highest floods. Planned a shortcut with a width of 40 meters and a height of 7 meters. The design of the angular dimensions shown in Figure 4.

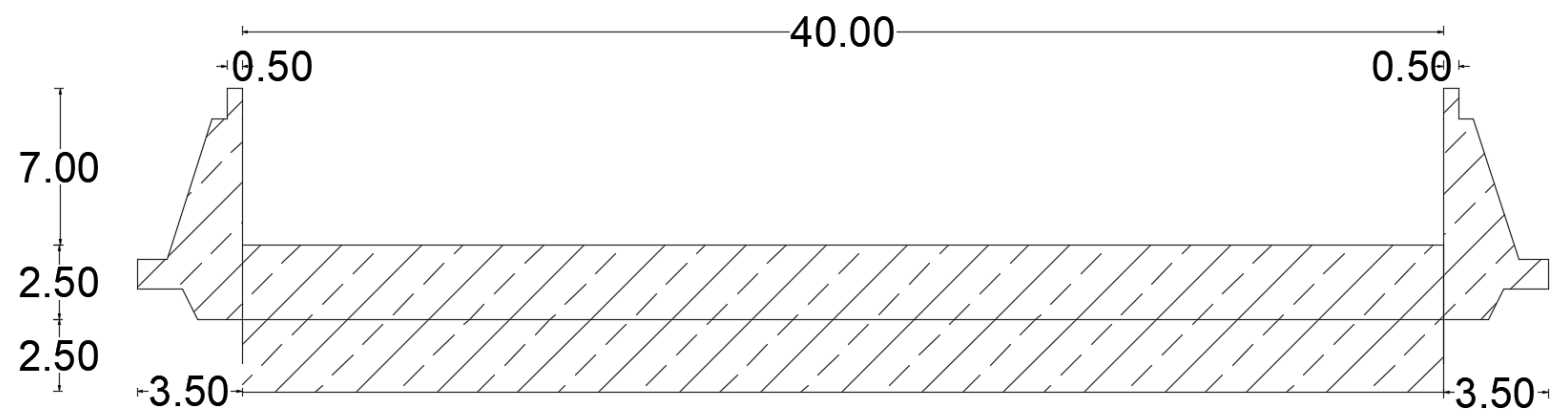

\section{Source : Research document (2021)}

Figure 4. Shortcut Dimension Design

\subsection{HEC-RAS Model}

Next, the HEC-RAS running model is carried out in the unsteady flow conditions on the terrain with and without the corners. Analyzed flow and flood inundation conditions were at various times. The flood inundation simulation is reviewed based on 25, 50, 100, 200, and 1000 years of return period discharge. The results of modeling a flood inundation with and without a shortcut can seen in Figure 5.

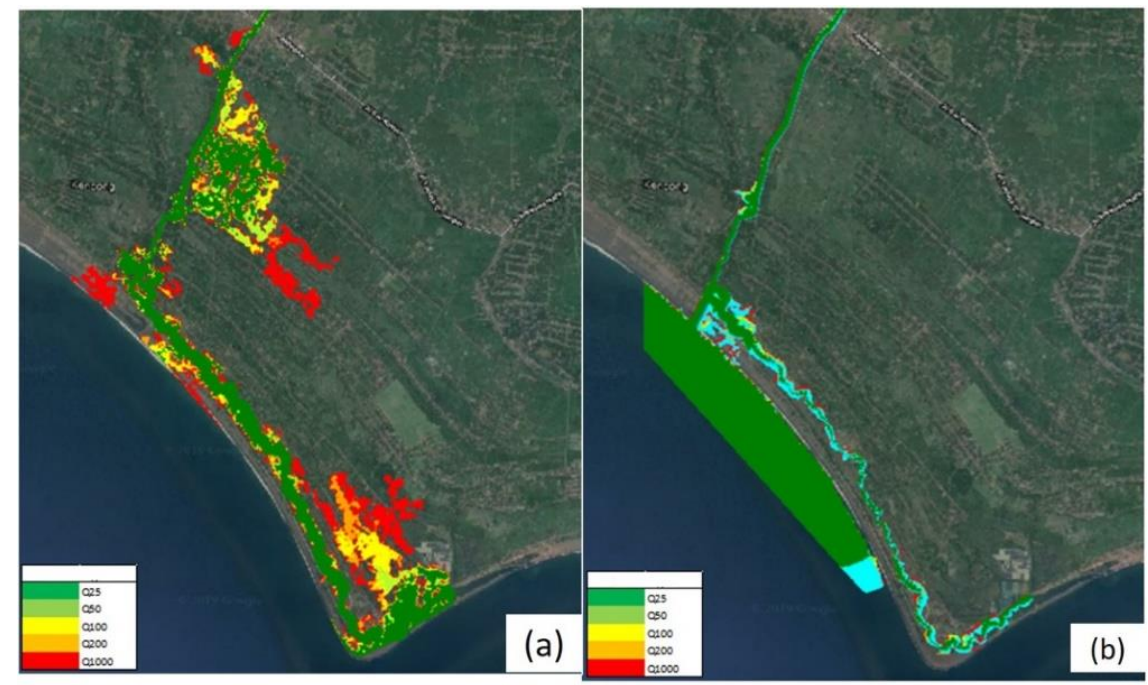

Source : Research document (2021)

Figure 5. Result of Distribution of Flood Inundation without Shortcut (a) and with a shortcut (b) 
Based on Figure 5, the flood discharge during the 25 year return period $\left(541.6 \mathrm{~m}^{3} / \mathrm{s}\right)$ has overtopping. This condition is due to downstream narrowing and water level rise (high tide), resulting in a slowing flow. In addition, the sediment in the river mouth is also causing a reduction in flow velocity.

\subsection{Flood Inundation Analysis}

The results of the flood inundation area are obtained from calculations using ArcGIS 10.1. Based on Figures 6 and 7, the distribution of floods in the Tanggul watershed has increased along with the increase in the return period of the flood discharge, and the shortcut has a significant impact based on the area of flood inundation. The largest flood inundation occurred in the middle of the river about $2 \mathrm{~km}$ from the Pondokwaluh Dam.

The condition of the flood inundation distribution and its depth will be more widespread if the flood occurs over the 200 year return period. The distribution of inundation during the 100-year return flood will result in an inundation of 640 hectares. Meanwhile, the 200 and 1000 year return floods will cause an inundation of 786 and 1226 ha. The results of modeling the full area of flood inundation at various return periods shown in Figure 6.

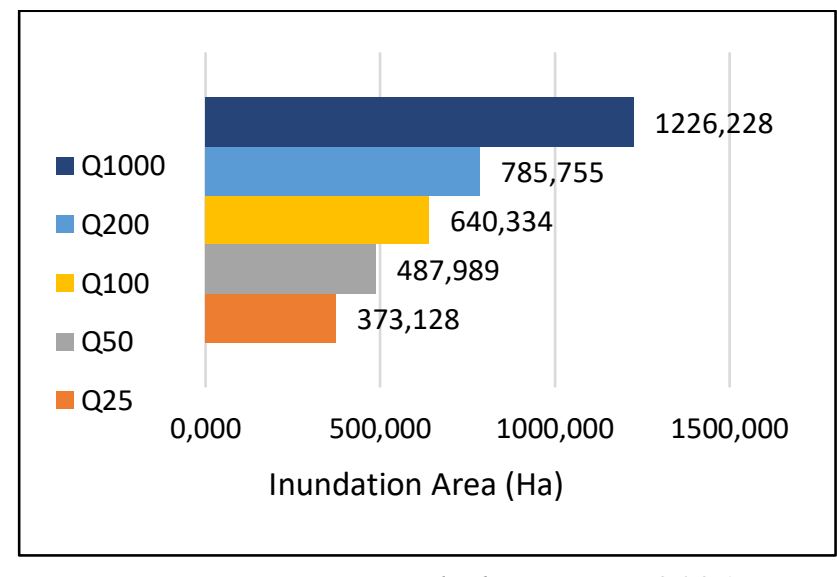

Source : Research document (2021)

Figure 1. The Total Area of Flood InundationWithout Shortcut at Various Times

Subsequently, a simulation of reducing the flood inundation area was carried out by creating a shortcut near the end of the main river to the sea. The running model is carried out on various return periods of flooding so that the sliding performance effect on the reduction of flood inundation can be obtained. The result shows a very significant decrease. Based on the flood inundation analysis using ArcGIS, The 200-year return flood without and with a shortcut will reduce the flood inundation area from $786 \mathrm{Ha}$ to $11.2 \mathrm{Ha}$. The amount of flood reduction can be seen in Figure 7. 


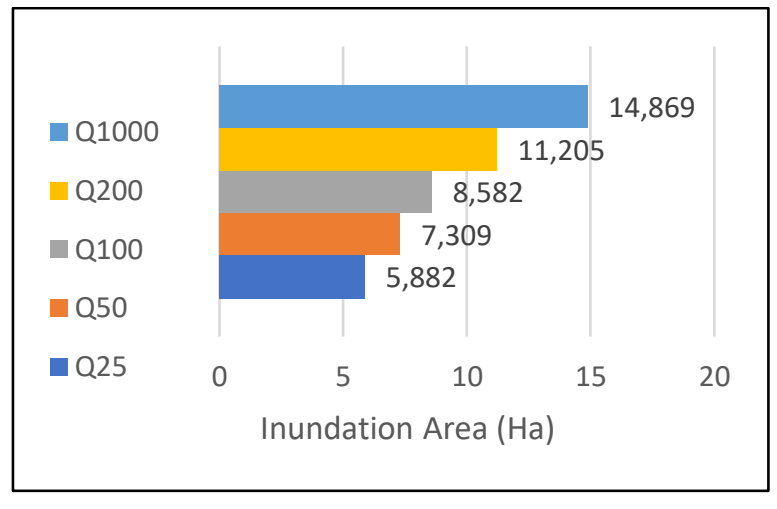

Source : Research document (2021)

Figure 2. The Total Area of Flood Inundation with Shortcut at Various Times of Return

\subsection{Model Validation}

Model validation is carried out to determine the suitability of research with real conditions. Validation was carried out using the discharge, depth, and coordinate points recorded during the flood events from 2013 to 2016. The recorded discharge was 685,866 m3 / $\mathrm{s}$ to $717,2867 \mathrm{~m} 3 / \mathrm{s}$ with a depth of $1.25 \mathrm{~m}$ to $1.5 \mathrm{~m}$ in Kraton Village and Paseban Village. The results of model simulation according to their depth can be seen in Table 2 and Table 3. At the same time, the results of the coordinate point validation based on the flood inundation risk map model are shown in Figure 8.

Table 2. The Depth of the Flood Inundation Model Simulation Results Without a Shortcut

\begin{tabular}{ccccccc}
\hline Return Period Discharge & Q25 & Q50 & Q100 & Q200 & Q1000 \\
\cline { 2 - 7 }$\left(\mathrm{m}^{3} / \mathrm{s}\right)$ & 468.49 & 541.63 & 622.73 & 702.73 & 934.10 \\
\hline & $\begin{array}{c}\text { Kraton } \\
\text { Village }\end{array}$ & 0.893 & 1.063 & 1.186 & 1.274 & 1.732 \\
\cline { 2 - 7 } Max.Depth (m) & $\begin{array}{c}\text { Kencong } \\
\text { Village }\end{array}$ & 0.597 & 0.729 & 0.826 & 0.898 & 1.310 \\
\cline { 2 - 7 } & $\begin{array}{c}\text { Paseban } \\
\text { Village }\end{array}$ & 1.245 & 1.382 & 1.479 & 1.550 & 2.137 \\
\hline
\end{tabular}

Source : Research document (2021)

Based on Table 2, the maximum depth of flood inundation without shortcut happens in Paseban Village with the depth of 1.5 meters, and with a shortcut (based on Table 3), there is no more flood inundation.

Table 3. The Depth of the Flood Inundation Model Simulation Results With a Shortcut

\begin{tabular}{ccccccc}
\hline $\begin{array}{c}\text { Return Period Discharge } \\
\left(\mathrm{m}^{3} / \mathrm{s}\right)\end{array}$ & Q25 & Q50 & Q100 & Q200 & Q1000 \\
\cline { 2 - 6 } & 468.49 & 541.63 & 622.73 & 702.73 & 934.10 \\
\hline $\begin{array}{c}\text { Max.Depth } \\
(\mathrm{m})\end{array}$ & $\begin{array}{c}\text { Kraton } \\
\text { Village }\end{array}$ & - & - & - & - & - \\
\hline
\end{tabular}




\begin{tabular}{|c|c|c|c|c|c|c|}
\hline \multirow{2}{*}{\multicolumn{2}{|c|}{$\begin{array}{l}\text { Return Period Discharge } \\
\qquad\left(\mathrm{m}^{3} / \mathrm{s}\right)\end{array}$}} & Q25 & Q50 & Q100 & Q200 & Q1000 \\
\hline & & 468.49 & 541.63 & 622.73 & 702.73 & 934.10 \\
\hline & $\begin{array}{c}\text { Kencong } \\
\text { Village }\end{array}$ & 0.177 & 0.232 & 0.394 & 0.472 & 0.619 \\
\hline $\begin{array}{l}\text { Max.Depth } \\
\text { (m) }\end{array}$ & $\begin{array}{c}\text { Paseban } \\
\text { Village }\end{array}$ & - & - & - & - & - \\
\hline
\end{tabular}

Source : Research document (2021)

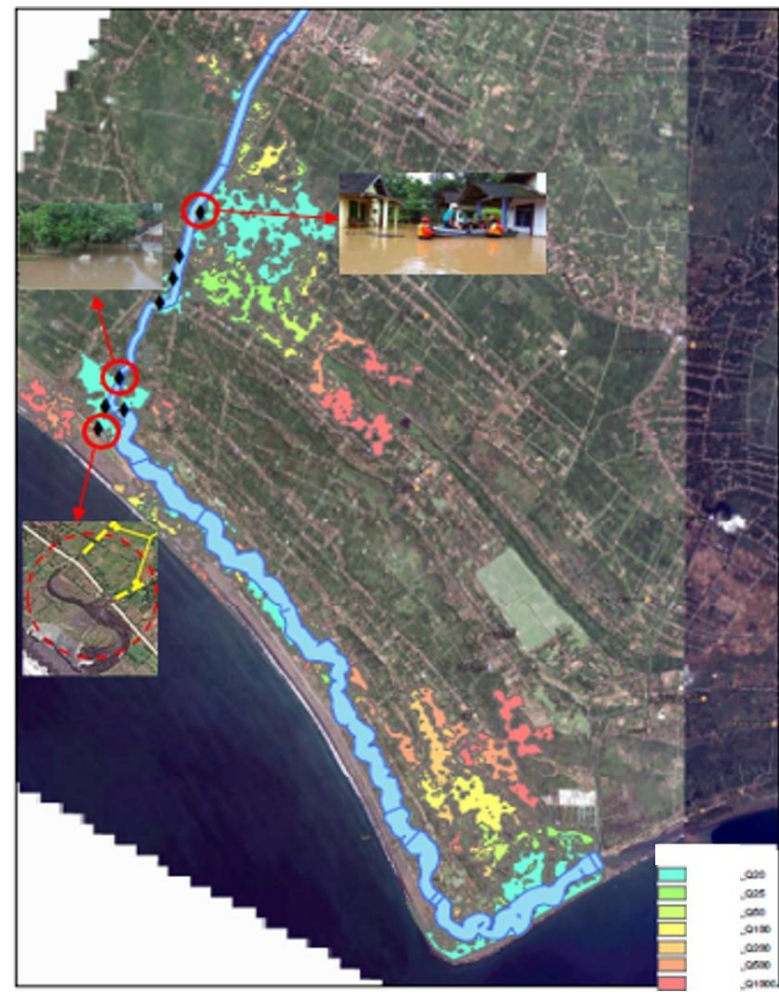

Source : Research document (2021)

Figure 3. Flood Hazard Map

Based on the model's output, the discharge and depth at the return period of 200 are close to the figures recorded from 2013 to 2016. In addition, the location of the flood event (overtopping) from the modeling results is close to or has a corresponding coordinate point of the existing flood event.

The distribution and flood inundation depth in the studied locations (Kraton, Kencong, and Paseban Village) showed variations in the flood inundation depth. In the 200-year return flood, the inundation height varied from $0.90 \mathrm{~m}$ to $1.55 \mathrm{~m}$. If simulated by a shortcut, there will be a flood-free area in Kraton and Paseban Village, while in Kencong Village, there will be a decrease of flood inundation depth to $0.47 \mathrm{~m}$. 
The shortcut by hydraulic performance can reduce flooding effectively and efficiently. However, it is necessary to consider the details of the floodgates located downstream of the shortcut. In addition, it is also necessary to plan/consider the arrangement of the floodgates in high tide conditions. If possible, it is required to design automatic doors (automatic floodgate valves) that work based on the conditions of the upstream water level (flood water level) and the downstream conditions of the floodgate (tidal water level). 


\section{Conclusion and Suggestion}

\subsection{Conclusion}

Based on the results of running with the HEC-RAS and ArcGIS programs, the selection of shortcuts as a technical flood mitigation strategy has a very effective impact on the distribution of flood inundation in the Tanggul watershed. The shortcut planning is analyzed at the highest return period of flood discharge $(934.098 \mathrm{~m} 3 / \mathrm{s})$ with a width of 40 meters and 7 meters. Based on HEC-RAS analysis in the existing condition, floods already occur during 25 year return period $\left(541.6 \mathrm{~m}^{3} / \mathrm{s}\right)$, which is caused by downstream narrowing and water level rise. With shortcuts, the reduced distribution area of flood inundation, the height of flood inundation, and location points or areas affected by floods are proved by the reduced distribution area of flood inundation. The validation results show that the 200 -year return flood discharge is close to the discharge when a flood occurs with a depth of $1.25 \mathrm{~m}$ to $1.5 \mathrm{~m}$, and there is a match for the coordinates of the flood-hazard areas with the flood inundation model, which is the flood height decrease 0.47 to $0.56 \mathrm{~m}$.

\subsection{Suggestion}

To reduce the flood inundation at Tanggul river, a possible strategy is to build shortcuts, maintain river capacity with river normalization, and make a flood hazard map for the long-term development plan. 


\section{References}

[1] A. D. Wicaksono, E. Hidayah, and R. U. A. Wicaksono, "Flood Vulnerability Assessment of Kali Welang Floodplain by Using Analytic Hierarchy Process Based Methods," Ukarst J. Univ. Kadiri Ris. Tek. Sipil, vol. 5, no. 1, pp. 95-109, 2021, doi: 10.1016/j.gloenvcha.2006.03.008.

[2] G. H. J. P. September, E. Hidayah, "Assessment and Optimization of Water Division Pattern in Sampean Baru Irrigation Area," Ukarst J. Univ. Kadiri Ris. Tek. Sipil, vol. 5, no. 1, pp. 79-94, 2021.

[3] Z. K. Ma, Z. W. Fan, M. Zhang, and Y. L. Su, "Flood risk control of dams and dykes in middle reach of Huaihe River," Water Sci. Eng., vol. 7, no. 1, 2014, doi: 10.3882/j.issn.1674-2370.2014.01.003.

[4] J. Sanyal, "Uncertainty in levee heights and its effect on the spatial pattern of flood hazard in a floodplain," Hydrol. Sci. J., vol. 62, no. 9, 2017, doi: 10.1080/02626667.2017.1334887.

[5] C. Wenger, "Building walls around flood problems: The place of levees in Australian flood management," Australian Journal of Water Resources, vol. 19, no. 1. 2015, doi: 10.7158/13241583.2015.11465453.

[6] V. Demir and O. Kisi, "Flood Hazard Mapping by Using Geographic Information System and Hydraulic Model: Mert River, Samsun, Turkey,” Adv. Meteorol., vol. 2016, 2016, doi: 10.1155/2016/4891015.

[7] A. Azouagh, R. El Bardai, I. Hilal, and J. Stitou el Messari, "Integration of GIS and HEC-RAS in Floods Modeling of Martil River (Northern Morocco)," Eur. Sci. Journal, ESJ, vol. 14, no. 12, 2018, doi: 10.19044/esj.2018.v14n12p130.

[8] M. S. Khattak, F. Anwar, T. U. Saeed, M. Sharif, K. Sheraz, and A. Ahmed, "Floodplain Mapping Using HEC-RAS and ArcGIS: A Case Study of Kabul River," Arab. J. Sci. Eng., vol. 41, no. 4, 2016, doi: 10.1007/s13369-015-1915-3.

[9] R. L. Reddy, B. Apoorva, S. Snigdha, and K. Spandana, "GIS Applications in Land Use and Land Development of a City," Int. J. Emerg. Technol. Adv. Eng., vol. 3, no. 5, pp. 3-8, 2013.

[10] B. H. Narendra, H. H. Siringoringo, and C. A. Siregar, "GIS Based Flood Hazard and Vulnerability Mapping: A Case Study of Tidal and River Floods in Downstream of Ciasem Watershed, Subang-West Java," Indones. J. For. Res., vol. 4, no. 1, 2017, doi: 10.20886/ijfr.2017.4.1.37-48. 
[11] A. H. Oluwasegun, "GIS Analysis of flood vulnerable area in Benin-owena river basin Nigeria," Indones. J. Geogr., vol. 49, no. 1, 2017, doi: 10.22146/ijg.12777.

[12] P. A. D, J. Sarup, and S. K. Mittal, “Application of GIS for Flood Mapping: A Case Study of Pune City," Int. J. Mod. Trends Eng. Res., vol. 3, no. 4, 2016.

[13] P. Sun, S. Wang, H. Gan, B. Liu, and L. Jia, "Application of HEC-RAS for flood forecasting in perched river-A case study of hilly region, China," in IOP Conference Series: Earth and Environmental Science, 2017, vol. 61, no. 1, doi: 10.1088/17551315/61/1/012067.

[14] P. K. Parhi, "Flood Management in Mahanadi Basin using HEC-RAS and Gumbel's Extreme Value Distribution,” J. Inst. Eng. Ser. A, vol. 99, no. 4, pp. 751-755, 2018, doi: $10.1007 / \mathrm{s} 40030-018-0317-4$.

[15] A. Husain, "Flood Modelling by using HEC-RAS," Int. J. Eng. Trends Technol., vol. 50, no. 1, 2017, doi: 10.14445/22315381/ijett-v50p201.

[16] A. Sleibi, M. S. Oleiwi, S. Khalid, and M. Al_Alwani, “Application of HEC-RAS Model to Predict Sediment Transport for Euphrates River from Haditha to Heet 2016," J. Eng. Sci., vol. 20, no. 3, 2017.

[17] C. S. Pathak and D. Reinhart, Water, Wastewater, and Stormwater and Urban Watershed Symposium. 2016.

[18] R. Vijay, R. Gupta, and S. Dash, "Modelling approach for water quality assessment of Pili River using HEC-RAS,” J. Indian Water Work. Assoc., no. July 2018, 2017.

[19] H. Yunita, “ANALISIS GENANGAN BANJIR SUNGAI RONGKONG KABUPATEN LUWU UTARA SULAWESI SELATAN,” ISSN 2502-3632 ISSN 2356-0304 J. Online Int. Nas. Vol. 7 No.1, Januari - Juni 2019 Univ. 17 Agustus 1945 Jakarta, vol. 53, no. 9, pp. 1689-1699, 2019

[20] P. K. Bhola, B. B. Nair, J. Leandro, S. N. Rao, and M. Disse, "Flood inundation forecasts using validation data generated with the assistance of computer vision," $J$. Hydroinformatics, vol. 21, no. 2, pp. 240-256, 2019, doi: 10.2166/hydro.2018.044.

[21] M. Muthusamy, M. R. Casado, D. Butler, and P. Leinster, "Understanding the effects of Digital Elevation Model resolution in urban fluvial flood modelling," J. Hydrol., vol. 596, no. January, 2021, doi: 10.1016/j.jhydrol.2021.126088.

[22] P. D. Bates and A. P. J. De Roo, "A simple raster-based model for flood inundation simulation," J. Hydrol., vol. 236, no. 1-2, pp. 54-77, 2000, doi: 10.1016/S00221694(00)00278-X. 
[23] Z. Walczak, M. Sojka, R. Wrózyński, and I. Laks, "Estimation of polder retention capacity based on ASTER, SRTM and LIDAR DEMs: The case of Majdany Polder (West Poland)," Water (Switzerland), vol. 8, no. 6, 2016, doi: 10.3390/w8060230.

[24] R. Liu et al., "Integrating Entropy-Based Naïve Bayes and GIS for Spatial Evaluation of Flood Hazard," Risk Anal., vol. 37, no. 4, pp. 756-773, 2017, doi: 10.1111/risa.12698.

[25] T. Surwase, G. Srinivasarao, P. Manjusree, A. Begum, P. V Nagamani, and G. Jaisankar, Proceedings of International Conference on Remote Sensing for Disaster Management, no. September 2008. Springer International Publishing, 2019.

[26] N. Handajani, “Analisa Distribusi Hujan dengan Kala Ulang Tertentu,” J. Rekayasa Perenc., vol. 1, no. 3, 2005. 